\title{
Effect of tillage systems on soil properties, humus and water conservation
}

\author{
Teodor Rusu ${ }^{1 *}$, Ioan Pacurar ${ }^{1}$, Marcel Dirja ${ }^{1}$, Horea Mihai Pacurar ${ }^{1}$, Ioan Oroian ${ }^{1}$, \\ Smaranda Adina Cosma ${ }^{2}$, Marinela Gheres ${ }^{2}$ \\ ${ }^{1}$ University of Agricultural Sciences and Veterinary Medicine Cluj-Napoca, Romania; ${ }^{*}$ Corresponding Author: trusu@ usamvcluj.ro \\ ${ }^{2}$ University Babes - Bolyai Cluj-Napoca, Romania
}

Received 2013

\section{ABSTRACT}

Human action upon soil by tillage determines important morphological, physical-chemical and biological changes, with different intensities and evaluative directions. Nowadays, it is internationally accepted the fact that global climatic changes are the results of human intervention in the bio-geo-chemical water and material cycle, and the sequestration of carbon in soil is considered an important intervention to limit these changes. Carbon sequestration in soil is net advantageous, improving the productivity and sustainability. The more the organic content in soil is higher the better soil aggregation is. The soil without organic content is compact. This reduces its capacity to infiltrate water, nutrients solubility and productivity, and that way it reduces the soil capacity for carbon sequestration. Organic matter is an extremely important constituent of soils and is vital to many of the hydrological, biological and chemical reactions required for sustaining plant life. We present the influence of conventional plough tillage system on soil, water and organic matter conservation in comparison with an alternative minimum tillage system (paraplow, chisel plow and rotary harrow). The application of minimum tillage systems increased the organic matter content $0.8 \%$ to 22.1\% and water stabile aggregate content from $1.3 \%$ to $13.6 \%$, in the $0-30 \mathrm{~cm}$ depth, as compared to the classical system. For the organic matter content and the wet aggregate stability, the statistical analysis of the data showed, increasing positive significance of minimum systems. While the soil fertility and the wet aggregate stability were initially low, the effect of conservation practices on the soil features resulted in a positive impact on the water permeability of the soil. Availability of soil moisture during the crop growth resulted in better plant water status. Subsequent release of conserved soil water regulated proper plant water status, soil structure, and lowered soil pene-trometer resistance.

Keywords: Soil Tillage; Water Management; Carbon Sequestration

\section{INTRODUCTION}

Soil Tillage Conservation (STC) are considered major components of agricultural technology for soil conservation strategies and part of Sustainable Agriculture (SA). STC involves reducing the number of tillage to direct sowing and plant remains at the soil surface in the ratio of at least $30 \%$. STC aims to ensure an appropriate aerohydric regim for the biological activity and balance in nutrient solubilisation $[2,4,6]$. Plant debris left on the soil surface or superficial incorporated contributes to increased biological activity and is an important source of $\mathrm{CO}_{2}$. STC restore soil structure and improve overall soil drainage, allowing more rapid infiltration of water into soil $[1,5]$. The result is a more productive soil, better protected against wind and water erosion and requires less fuel for preparing the germinative bed $[13,15,16]$. Research conducted, throughout the world show that not so much the chosen rotation affects the amount of carbon sequestered but rather the influence of rotation on the recovery of soil structure, affecting both productivity and reduce erosion [8]. A large amount of $\mathrm{CO}_{2}$ produced in the soil and released into the atmosphere, resulting from aerobic processes of mineralization of organic matter (excessive lossening) is considered not only a way of increasing $\mathrm{CO}_{2}$ in the atmosphere, but also a loss of longterm of soil fertility. This indicates an accelerated mineralization of soil organic matter and degradation of soil pedogenetical process. STC significantly modify the amount of $\mathrm{CO}_{2}$ released into the atmosphere. Thus, Derpsch and Moriya, 1998 [1] calculated a quantity of 
400 million tones of carbon stored in arable soils in the US, in 2020 (if no-tillage system will be applied on $76 \%$ of the arable land), with influence on the conservation of soil fertility and climate change.

The purpose of this paper was to evaluate the soil properties, especially water and soil organic matter conservation, in classic soil tillage systems versus three minimum soil tillage variants in the pedoclimatic conditions in Cluj-Napoca $\left(46^{\circ} 46^{\prime} \mathrm{N}, 26^{\circ} 36^{\prime} \mathrm{E}\right)$, Romania. Conventional tillage means, in Romania as elsewhere, the autumn plough tillage at approximately $20-25 \mathrm{~cm}$, followed by disc harrow work in the spring and sowing fertilizer and seed via drill. This practice accounts for a number of problems such as soil degradation, erosion, compaction and waterway pollution $[7,12,14]$. While conventional soil tillage (basic working, preparation of the germinal layer, maintenance of the field etc.) results in immediate positive effects, some negative effects also manifest themselves. One of the main objectives for the soil tillage system is to create an optimal physicochemical state of the soil and to preserve this state over the whole vegetation period. This study, conducted under different bioclimatic conditions, shows that the soil tillage system directly influences soil properties [9-11,17-19].

Carbon sequestration in soil has clear advantages, such as improving the productivity and sustainability. The higher the organic content in soil is the better the soil aggregation is. The soil without organic content is compact. This reduces its capacity to infiltrate water, nutriaents solubility and productivity, and implicitly it reduces the soil capacity for carbon sequestration $[3,14]$. Furthermore, it increases soil vulnerability to erosion through water and wind. Soil carbon dioxide concentration dynamics can be presently continuously monitored using the latest available sensors. Systems for soil gas measurements offer crucial information regarding production, consumption, and gas transportation, with major implications in quantitative and qualitative assessment of soil respiration and soil aeration.

\section{MATERIAL AND METHODS}

The influence of tillage soil system upon water supply accumulated in soil was studied on several soil types
(Table 1, $[20,22])$ at the University of Agricultural Sciences and Veterinary Medicine of Cluj Napoca. The experimental soil tillage systems were as follows:

Classic system: $\mathrm{V}_{1}-$ classic plough + disc $-2 \mathrm{x}$ (witness).

Minimum tillage systems: $\mathrm{V}_{2}$ - paraplow + rotary harrow, $\mathrm{V}_{3}$ - chisel plow + rotary harrow, $\mathrm{V}_{4}$ - rotary harrow.

To quantify the change in soil properties under different tillage practices, determinations were made for each cultivar (maize - Zea mays L., soy-bean - Glycine hispida L. Merr., wheat - Triticum aestivum L., spring rape Brassica napus L. var. oleifera D.C. / potato - Solanum tuberosum L.) in four vegetative stages (spring, 5 - 6 leaves, bean forming, harvest). Soil parameters monitored included soil water content (gravimetric method, Aquaterr probe - Frequency domain reflectometry), soil bulk density (determined by volumetric ring method using the volume of a ring $100 \mathrm{~cm}^{3}$ ), soil penetration (using a Fieldscout SC900 Penetrometer), water stable aggregates, soil permeability (using the Infiltrometer method) and organic matter content. The average result values, obtained in the vegetal phases were statistically analyzed, using the last four cultivation years within the crop rotation for every type of soil. The results were analyzed using ANOVA and Duncan's test [21]. A significance level of $\mathrm{P} \leq 0.05$ was established a priori. Measuring the $\mathrm{CO}_{2}$ content in the soil was conducted through the gradient method by using a new generation of sensors (GMD20 and GMM220) capable of measuring in-situ and quasi-instantaneous the concentration of gaseous $\mathrm{CO}_{2}$ in the soil at three depths: 4,8 and $22 \mathrm{~cm}$.

\section{RESULTS AND DISCUSSION}

The soil tillage has as a main purpose a series of immediate effects (with a positive part), results from the objectives of the soil tillage themselves: basic working, preparing the germinal layer, maintaining the field. Often though the effects of the soil tillage over this one can have an immediate negative part or lasting effects, remaining (positive or negative). Long-term field experiments provide excellent opportunities to quantify the long-term effects of soil tillage systems on accumulated soil water. The hydrological function of the soil

Table 1. Initial select soil properties $(0-20 \mathrm{~cm})$ on different soil types at the experimental area near the University of Agricultural Sciences and Veterinary Medicine, Cluj Napoca, Romania.

\begin{tabular}{|c|c|c|c|c|c|c|}
\hline $\begin{array}{c}\text { Type of soil } \\
\text { (WRB-SR, 1998) }\end{array}$ & Clay content, \% & Humus, \% & $\begin{array}{c}\text { WSA, } \\
\%\end{array}$ & pH & $\begin{array}{c}\text { P.m.m., } \\
\text { mm }\end{array}$ & $\begin{array}{c}\text { T.m.m, } \\
{ }^{\circ} \mathrm{C}\end{array}$ \\
\hline Chernozem cambic & 43.1 & 3.52 & 78 & 6.73 & 500 & 8.8 \\
\hline Phaeozem tipic & 43.2 & 3.92 & 76 & 6.71 & 500 & 8.8 \\
\hline Haplic luvisols & 42.0 & 2.49 & 65 & 6.06 & 613 & 8.2 \\
\hline Fluvisol molic & 41.6 & 3.01 & 61 & 7.25 & 613 & 8.2 \\
\hline
\end{tabular}

WSA - Water stabilite macro-aggregation; P.m.m. - Precipitation medium multi-annual; T.m.m. - Temperature medium multi-annual. 
(especially the capacity to retain an optimum water quantity, and then gradually make this available for plant consumption) is one of the most important functions determining soil fertility, productivity and soil evolution. Intrinsic soil properties such as organic matter and texture, along with applied tillage practices combine to modify the soil structure, porosity, permeability and water capacity. This, in turn, is a critical factor in the water cycle and affects water accumulation in the soil.

Statistical analysis of the results showed that the differences in accumulated soil water depended on the variants of soil tillage and type of soil. Soil texture and structure have a strong effect on the available water capacity. The results clearly demonstrate that minimum tillage systems promote increased humus content $(0.8 \%$ $22.1 \%$ ) (Table 2) and increased water stabile aggregate content $(1.3 \%-13.6 \%)$ at the $0-30 \mathrm{~cm}$ depth compared to conventional tillage (Table 3 ).

Statistical analysis regarding the organic matter content of the studied systems shows significant positive values on Haplic luvisols under paraplow and chisel tillage as well on Typic Phaeozems under paraplow and rotary harrow tillage. Multiple comparisons between systems indicate advantages for using the paraplow on Phaeozems (b), chisel on Haplic luvisols (b) and rotary harrow Molic Fluvisol (b). Multiple analysis of soil classification and tillage system on the hydric stability of soil structure have shown that all variants with minimum tillage are superior $(\mathrm{a}, \mathrm{b}, \mathrm{c})$, having a positive influence on soil structure stability.

The increase of organic matter content is due to the vegetal remnants partially incorporated and adequate biological activity in this system. In the case of humus content and also the hydro stability structure, the statistical interpretation of the dates shows an increasing positive significance of the minimum tillage systems application. The soil fertility and wet aggregate stability were initially low, the effect being the conservation of the soil features and also their reconstruction, with a positive influence upon the permeability of the soil for water. More aggregated soils permit more water to reach the root zone. This not only increases productivity, it may also reduce runoff, and thus erodibility potential.

Table 2. The influence of soil tillage system upon organic matter content (OM, \%; 0 - $30 \mathrm{~cm})$.

\begin{tabular}{|c|c|c|c|c|c|}
\hline Type of soil & Soil tillage systems & $\begin{array}{l}\text { Classic plough } \\
+ \text { disc }-2 \mathrm{x}\end{array}$ & $\begin{aligned} & \text { Paraplow } \\
+ & \text { rotary harrow }\end{aligned}$ & $\begin{aligned} & \text { Chisel plow } \\
&+ \text { rotary harrow }\end{aligned}$ & Rotary harrow \\
\hline \multirow{2}{*}{ Chernozem cambic } & $\mathrm{OM}, \%$ & $3.51 \mathrm{a}$ & $3.54 \mathrm{a}$ & $3.87 \mathrm{a}$ & $3.61 \mathrm{a}$ \\
\hline & Significance (\%) & wt. $(100)$ & ${ }^{\mathrm{ns}}(100.8)$ & ${ }^{\mathrm{ns}}(110.2)$ & ${ }^{\mathrm{ns}}(102.8)$ \\
\hline \multirow{2}{*}{ Phaeozem tipic } & $\mathrm{OM}, \%$ & $3.90 \mathrm{a}$ & $4.13 \mathrm{~b}$ & $3.93 \mathrm{ab}$ & $3.98 \mathrm{ab}$ \\
\hline & Significance (\%) & wt. $(100)$ & $*(106.0)$ & ${ }^{\mathrm{ns}}(100.9)$ & ${ }^{\mathrm{ns}}(102.2)$ \\
\hline \multirow{2}{*}{ Haplic luvisols } & $\mathrm{OM}, \%$ & $2.48 \mathrm{a}$ & $2.94 \mathrm{ab}$ & $3.02 \mathrm{~b}$ & $2.82 \mathrm{ab}$ \\
\hline & Significance (\%) & wt. $(100)$ & $*(118.6)$ & $*(122.1)$ & ${ }^{\mathrm{ns}}(113.9)$ \\
\hline \multirow{2}{*}{ Fluvisol molic } & $\mathrm{OM}, \%$ & $3.03 \mathrm{a}$ & $3.12 \mathrm{ab}$ & $3.09 \mathrm{ab}$ & $3.23 \mathrm{~b}$ \\
\hline & Significance (\%) & wt. $(100)$ & ${ }^{\mathrm{ns}}(103.1)$ & ${ }^{\mathrm{ns}}(102.0)$ & ${ }^{\mathrm{ns}}(106.5)$ \\
\hline
\end{tabular}

Note: OM- organic matter; wt - witness, ns - not significant, $*$ positive significance, ${ }^{0}$ negative significance, a, ab, b, c - Duncan's classification (the same letter within a row indicates that the means are not significantly different.)

Table 3. The influence of soil tillage system upon water stability of structural macro-aggregates (WSA, \%; $0-30 \mathrm{~cm}$ ).

\begin{tabular}{|c|c|c|c|c|c|}
\hline Type of soil & Soil tillage systems & $\begin{array}{l}\text { Classic plough } \\
\quad+\text { disc }-2 x\end{array}$ & $\begin{aligned} & \text { Paraplow } \\
+ & \text { rotary harrow }\end{aligned}$ & $\begin{aligned} & \text { Chisel plow } \\
+ & \text { rotary harrow }\end{aligned}$ & Rotary harrow \\
\hline \multirow{2}{*}{ Chernozem cambic } & WSA, $\%$ & $74.33 \mathrm{a}$ & $79.00 \mathrm{~b}$ & $78.67 \mathrm{ab}$ & $80.33 \mathrm{~b}$ \\
\hline & Signification (\%) & wt. $(100)$ & $*(106.3)$ & ${ }^{\mathrm{ns}}(105.8)$ & $*(108.1)$ \\
\hline \multirow{2}{*}{ Phaeozem tipic } & WSA, $\%$ & $80.00 \mathrm{a}$ & $82.33 \mathrm{~b}$ & $81.00 \mathrm{ab}$ & $81.67 \mathrm{ab}$ \\
\hline & Signification (\%) & wt. $(100)$ & $*(102.9)$ & ${ }^{\mathrm{ns}}(101.3)$ & ${ }^{\mathrm{ns}}(102.1)$ \\
\hline \multirow{2}{*}{ Haplic luvisols } & WSA, $\%$ & $63.67 \mathrm{a}$ & $68.33 \mathrm{~b}$ & $66.67 \mathrm{ab}$ & $72.33 \mathrm{c}$ \\
\hline & Signification (\%) & wt. $(100)$ & $*(107.3)$ & $*(104.7)$ & $* *(113.6)$ \\
\hline \multirow{2}{*}{ Fluvisol molic } & WSA, $\%$ & $71.33 \mathrm{a}$ & $76.00 \mathrm{~b}$ & $75.33 \mathrm{~b}$ & $76.33 \mathrm{~b}$ \\
\hline & Signification (\%) & wt. $(100)$ & $*(106.5)$ & $*(105.6)$ & $*(107.0)$ \\
\hline
\end{tabular}


The minimum soil tillage systems and the replacement of ploughing by paraplow, chisel and rotary harrow work minimise soil aeration. The bulk density values at $0-50$ cm (Table 4) increased by $0-4.7 \%$ under minimum tillage systems. This raise was not significant in any of the experimental variants. Multiple comparing and classifycation of experimental variants align all values on the same level of significance (a).

The soil resistance to penetration, presented as an average of determinations on the four types of soil, shows a stratification tendency of soil profiles within the plough variant, where values are under $1000 \mathrm{kPa}$ up to the 20-22 $\mathrm{cm}$ depth and then suddenly increase over $3500 \mathrm{kPa}$ below this depth. The significant differences were determined in the minimum tillage systems at $10-20 \mathrm{~cm}$, where the values of resistance to penetration range between $1500-2500 \mathrm{kPa}$. Thus, in the variants worked with minimum tillage system, the soil profile stratification is significantly reduced.

After ten years of applying the same soil tillage system, the data show that soil infiltration and soil water retention are higher when working with paraplow and chisel plow variant with values of 5.54 (c) and 5.08 (b) $1 / \mathrm{m}^{2} / \mathrm{min}$, respectively. By contrast, the amount of water retained by traditional tillage was 4.25 (a) $1 / \mathrm{m}^{2} / \mathrm{min}$. The paraplow and chisel plow treatments were more favourable for infiltration and water retention. Positive effects on the saturated hydraulic conductivity of the paraplow (35.7 $\mathrm{cm} / \mathrm{h})$ and chisel plow $(31.5 \mathrm{~cm} / \mathrm{h})$ treated soils were observed compared with the traditional tillage $(29.4 \mathrm{~cm} / \mathrm{h})$ of the soil.

On haplic Luvisols, a soil with a moderately developed structure and average fertility, the quantity of water accumulated was 1\% - 6\% higher under paraplow (b), chisel plow and rotary harrow tillage, compared to conven- tional tillage (Table 5). On molic Fluvisols and cambic Chernozems, soils with good permeability, high fertility, and low susceptibility to compaction, accumulated water supply was higher (representing $11 \%-15 \%$ ) for all mini- mum soil tillage systems. In the four soils tested, the paraplow was the better at water conservation (as evi- denced by multiple comparisons and variants $-b$, c), showing an increase in the water reserve in soil of $4.8 \%-12.3 \%$.

Table 4. The effect of soil tillage system on the bulk density (BD, g/ $\mathrm{cm}^{3}, 0-50 \mathrm{~cm}$ ).

\begin{tabular}{|c|c|c|c|c|c|}
\hline Type of soil & Soil tillage systems & $\begin{array}{l}\text { Classic plough } \\
\quad+\text { disc }-2 x\end{array}$ & $\begin{aligned} & \text { Paraplow } \\
+ & \text { rotary harrow }\end{aligned}$ & $\begin{aligned} & \text { Chisel plow } \\
+ & \text { rotary harrow }\end{aligned}$ & Rotary harrow \\
\hline \multirow{2}{*}{ Chernozem cambic } & $\mathrm{BD}, \mathrm{g} / \mathrm{cm}^{3}$ & $1.32 \mathrm{a}$ & $1.38 \mathrm{a}$ & $1.37 \mathrm{a}$ & $1.36 \mathrm{a}$ \\
\hline & Signification (\%) & wt. $(100)$ & ${ }^{\mathrm{ns}}(104.7)$ & ${ }^{\mathrm{ns}}(103.9)$ & ${ }^{\mathrm{ns}}(103.3)$ \\
\hline \multirow{2}{*}{ Phaeozem tipic } & $\mathrm{BD}, \mathrm{g} / \mathrm{cm}^{3}$ & $1.22 \mathrm{a}$ & $1.23 \mathrm{a}$ & $1.25 \mathrm{a}$ & $1.22 \mathrm{a}$ \\
\hline & Signification (\%) & wt..(100) & ${ }^{\mathrm{ns}}(100.8)$ & ${ }^{\mathrm{ns}}(101.9)$ & ${ }^{\mathrm{ns}}(100.0)$ \\
\hline \multirow{2}{*}{ Haplic luvisols } & $\mathrm{BD}, \mathrm{g} / \mathrm{cm}^{3}$ & $1.32 \mathrm{a}$ & $1.35 \mathrm{a}$ & $1.34 \mathrm{a}$ & $1.35 \mathrm{a}$ \\
\hline & Signification (\%) & wt. $(100)$ & ${ }^{\mathrm{ns}}(102.4)$ & ${ }^{\mathrm{ns}}(101.7)$ & ${ }^{\mathrm{ns}}(102.4)$ \\
\hline \multirow{2}{*}{ Fluvisol molic } & $\mathrm{BD}, \mathrm{g} / \mathrm{cm}^{3}$ & $1.34 \mathrm{a}$ & $1.34 \mathrm{a}$ & $1.35 \mathrm{a}$ & $1.34 \mathrm{a}$ \\
\hline & Signification (\%) & wt.. $(100)$ & ${ }^{\mathrm{ns}}(100.0)$ & ${ }^{\mathrm{ns}}(100.6)$ & ${ }^{\mathrm{ns}}(100.0)$ \\
\hline
\end{tabular}

Table 5. The effect of soil tillage system on the water supply accumulated in soil $\left(\mathrm{W}, \mathrm{m}^{3} / \mathrm{ha} ; 0-50 \mathrm{~cm}\right)$.

\begin{tabular}{|c|c|c|c|c|c|}
\hline Type of soil & Soil tillage systems & $\begin{array}{l}\text { Classic plough } \\
\quad+\text { disc }-2 x\end{array}$ & $\begin{aligned} & \text { Paraplow } \\
+ & \text { rotary harrow }\end{aligned}$ & $\begin{aligned} & \text { Chisel plow } \\
+ & \text { rotary harrow }\end{aligned}$ & Rotary harrow \\
\hline \multirow{2}{*}{ Chernozem cambic } & $\mathrm{W}, \mathrm{m}^{3} / \mathrm{ha}$ & 936 a & $1.051 \mathrm{~b}$ & $1.047 \mathrm{~b}$ & $1.039 \mathrm{~b}$ \\
\hline & Signification (\%) & wt. $(100)$ & $*(112.3)$ & *(111.9) & $*(111.0)$ \\
\hline \multirow{2}{*}{ Phaeozem tipic } & $\mathrm{W}, \mathrm{m}^{3} / \mathrm{ha}$ & $842 \mathrm{a}$ & $882 \mathrm{~b}$ & 875 a & 859 a \\
\hline & Signification (\%) & wt.. $(100)$ & $*(104.8)$ & ${ }^{\mathrm{ns}}(103.9)$ & ${ }^{\mathrm{ns}}(102.0)$ \\
\hline \multirow{2}{*}{ Haplic luvisols } & $\mathrm{W}, \mathrm{m}^{3} / \mathrm{ha}$ & $850 \mathrm{a}$ & $901 \mathrm{~b}$ & $870 \mathrm{a}$ & 859 a \\
\hline & Signification (\%) & wt. $(100)$ & $*(106.0)$ & ${ }^{\mathrm{ns}}(102.3)$ & ${ }^{\mathrm{ns}}(101.0)$ \\
\hline \multirow{2}{*}{ Fluvisol molic } & $\mathrm{W}, \mathrm{m}^{3} / \mathrm{ha}$ & $878 \mathrm{a}$ & $1.010 \mathrm{c}$ & 998 b & $987 \mathrm{~b}$ \\
\hline & Signification (\%) & wt.. $(100)$ & $*(115.0)$ & $*(113.7)$ & $*(112.4)$ \\
\hline
\end{tabular}


Continuous measurement of $\mathrm{CO}_{2}$ concentrations and gas flow calculations on the surface, by estimating the diffusion coefficient of soil, reveals reduplication of the amount issued in the case of the classic version plough. An exceeding amount of $\mathrm{CO}_{2}$ produced in the soil and released into the atmosphere, resulting from aerobic processes of mineralization of organic matter (excessive loosening) is considered to be not only a way of increasing the $\mathrm{CO}_{2}$ in the atmosphere, but also a loss of longterm soil fertility. This indicates an acceleration of the mineralization process of soil organic matter and of the pedogenetical process of soil degradation. Minimum tillage systems significantly alter the amount of $\mathrm{CO}_{2}$ released into the atmosphere, reducing to less than half its diffusion. Thus, based on the results achieved, it was estimated an amount of 6.9 million tons/year of carbon stored in arable soils of Romania, if the minimum tillage system would be implemented on $50 \%$ of the arable land, with influence on the soil fertility conservation and climate change.

\section{CONCLUSIONS}

Reduced tillage systems represent an alternative to conventional tillage. This study demonstrated that increased soil organic matter content, aggregation, and permeability are all promoted by minimum tillage systems. The implementation of such practices ensures a greater water reserve even across different soil types. The practice of reduced tillage is ideal for enhancing soil fertility, water holding capacity, and reducing erosion. The advantages of minimum soil tillage systems for Romanian pedoclimatic conditions can be used to improve methods in low producing soils with reduced structural stability on sloped fields, as well as measures of water and soil conservation on the whole ecosystem.

Presently, it is necessary to make a change concerning the concept of conservation practices and to consider a new approach regarding the control of erosion. The actual soil conservation must be looke upon beyond the traditional understanding of soil erosion. The real soil conservation is represented by carbon management. We need to focus on an upper level concerning conservation by focusing on soil quality. Carbon management is necessary for a complexity of matters including soil, water management, field productivity, biological fuel and climatic change.

\section{REFERENCES}

[1] Derpsch, R. and Moriya, K. (1998) Historical review of no-tillage cultivation of crops. Proceedings First JIRCAS Seminar on soybean research, Foz do Iguaçu, Brazil, JIRCAS Working Report, 13, 1-18.

[2] Dick, W.A., Mccoy, E.L., Edwards, W.M. and Lal, R.
(1994) Continuous application of no-tillage to Ohio soils. Agronomy Journal-Abstract, 83, 65-73. doi:10.2134/agronj1991.00021962008300010017x

[3] Fabrizzi, K.P., Garcia, F.O., Costa, J.L. and Picone, L.I.(2005) Soil water dynamics, physical properties and corn and wheat responses to minimum and no-tillage systems in the southern Pampas of Argentina. Soil and Tillage Research, 81, 57-69. doi:10.1016/j.still.2004.05.001

[4] Feiza, V., Deveikyte, I. and Simanskaite, D. (2005) Soil physical and agrochemical properties changes, weediness and yield of crops in long-term tillage experiment in Lithuania. Scientific publication, 48, 96-100.

[5] Gus, P. (1997) The influence of Soil Tillage on yield and on some soil characteristics. In Alternatives in Soil Tillage, Symposium Cluj-Napoca, 2, 151-155.

[6] Jitareanu, G., Ailincai, C. and Bucur, D. (2006) Influence of Tillage Systems on Soil Phsical and Chemical Caracteristics and Yield in Soybean and Maize Grown in the Moldavian Plain (North-Eastern Romania). In Soil Management for Sustainability, IUSS, Catena Verlag, Germany. 370-379,

[7] Lal, R. (2004) Soil erosion and the global carbon budget. Environment International, 29, 437-450. doi:10.1016/S0160-4120(02)00192-7

[8] Marin, D. I., Mihalache, M., Ciontu, C., Bolohan, C.and Ilie, L. (2011) Influence of soil tillage of pea, wheat and maize crop in the Moara Domneasca-Ilfov area. 5th International Symposium Soil Minimum Tillage System, Ed. Risoprint Cluj-Napoca. 111-118.

[9] Mark, A. Licht and Mahdi Al-Kaisi. (2004) Strip-tillage effect seedbed soil temperature and other soil physical properties. Soil and Tillage Research, 80, 233-249.

[10] Moroizumi, T. and Horino, H. (2002) The effects of tillage on soil temperature and soil water. Soil Science. 167, 548-559. doi:10.1097/00010694-200208000-00006

[11] Oldeman I., Penning de Vries, L., Scherr, F. and Sombatpanit, S. (2006) Response to land degradation. Enfield, USA: Science Publishers Inc, 344.

[12] Riley, H. C. F., Bleken, M. A, Abrahamsen, S., Bergjord, A. K. and Bakken, A. K. (2005) Effects of alternative tillage systems on soil quality and yield of spring cereals on silty clay loam and sandy loam soils in the cool, wet climate of central Norway. Soil and Tillage Research, 80, 79-93. doi:10.1016/j.still.2004.03.005

[13] Rusu, T. (2001) The influence of Minimum Soil Tillage upon the soil, yield and efficiency. $\mathrm{PhD}$ Thesis, University of Agricultural Sciences and Veterinary Medicine of Cluj-Napoca.

[14] Rusu, T., Gus, P., Bogdan, I., Moraru, P.I., Pop, A.I., Clapa, D., Marin, D.I., Oroian, I. and Pop, L.I. (2009) Implications of Minimum Tillage Systems on Sustainability of Agricultural Production and Soil Conservation. Journal of Food, Agriculture \& Environment, 7, 335-338.

[15] Raja, R. K., Vara Prasad, P. V. and Kakani, V. G. (2005) Crop response to elevated carbon dioxide and interactions with temperature: Cotton. Journal of Crop Improvment, 13, 157-161. doi:10.1300/J411v13n01_08 
[16] Reicosky, D.C. (2006) Carbon is the "C" that starts "C"onservation. Soil Scientist, USDA-Agricultural Research Service, North Central Soil Conservation, http://waswc.ait.ac.th/index.html.

[17] Tuba, Z. (2005) Is the Long - Term Elevated Air $\mathrm{CO}_{2}$ Environment Beneficial for Plants, Crops and Vegetation. Journal of Crop Improvment, 13, 1-6. doi:10.1300/J411v13n01 01

[18] Turcu, V.E., Jones, S.B. and Or, D. (2005) Continuous soil carbon dioxide and oxygen measurements and estimation of gradient-based gaseous flux. Vadose Zone Journal, 4, 1161-1169. doi:10.2136/vzj2004.0164

[19] Ulrich, S., Hofmann, B., Tischer, S. and Christen, O.
(2006) Influence of Tillage on Soil Quality in a Long Term Trial in Germany. In Soil Management for Sustainability, IUSS, Catena Verlag, Germany. 110-116.

[20] MESP (1987) Pedologic Studies Elaboration Metodology. Pedologic and Agrochemical Ins. Bucharest, 1-3.

[21] PoliFact (2008) ANOVA and Duncan's test pc program for variant analyses made for completely randomized polifactorial experiences. USAMV Cluj-Napoca.

[22] SRTS (2003) Romanian System of Soil Taxonomy. Ed. Estfalia, Bucharest, pp. 182.

[23] WRB-SR (1998) World Reference Base for Soil Resources. World Soil Resources Report 84. ISSS, ISRIC. 